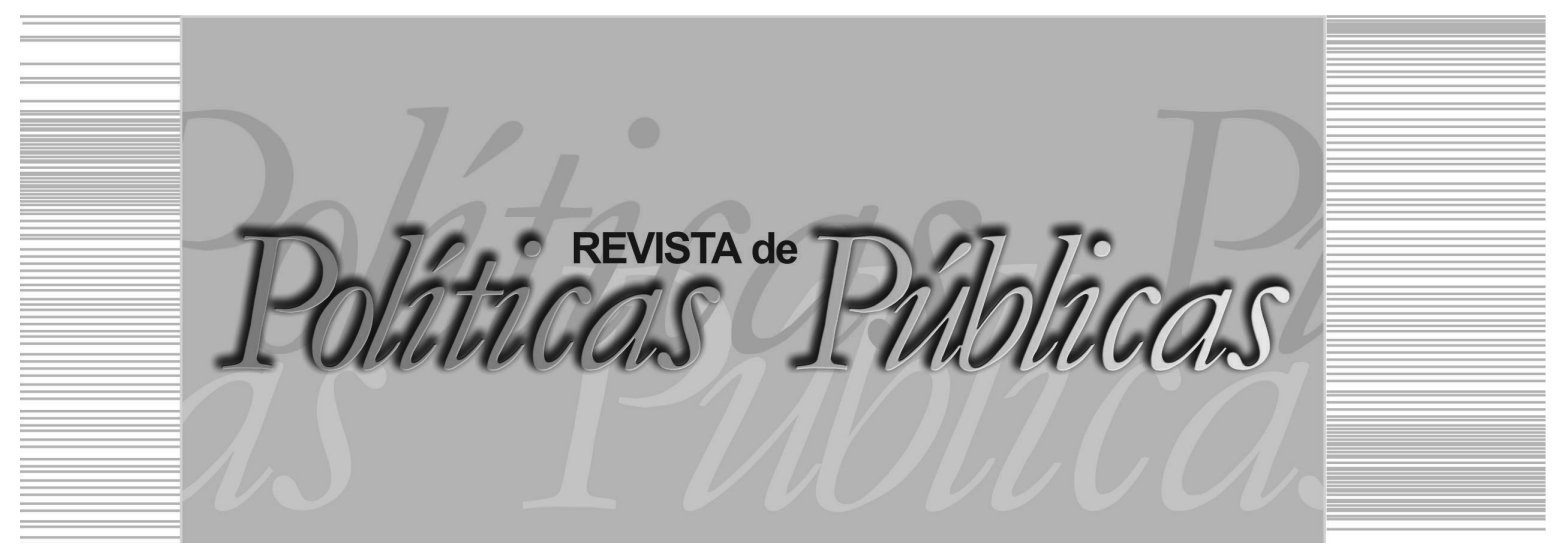

\title{
LAW 1.261/2015: obstacles to implement new public policies for tourism in São Paulo - Brazil
}

\author{
Cíntia Möller Araujo \\ Universidade Federal de São Paulo (UNIFESP)
}

\section{Resumo}

A Lei 1.261/2015 foi promulgada em abril de 2015 e propõe parâmetros democráticos e transparentes para avaliar as localidades turísticas, no estado de São Paulo. De fato, cria uma nova categoria de município turístico - i.e., os municípios de interesse turístico, além das atuais estâncias turísticas - e também apresenta um conjunto de requisitos técnicos para a seleção de ambas as categorias. A intenção deste trabalho é identificar os obstáculos para a implementação da referida lei, com o objetivo de avaliar sua eficácia. Para tanto, promoveu-se ampla pesquisa bibliográfica, utilizou-se a abordagem qualitativa e realizou-se um estudo de caso, que inclui pesquisa documental e outros procedimentos metodológicos, visando coletar informações (e.g. observação participante, entrevistas semiestruturadas e focadas). Identificaram-se vários obstáculos que dificultam a materialização dos direitos anunciados pela referida lei, os quais sugerem que sua implementação deverá ocorrer apenas daqui a alguns anos e este cenário compromete a sua eficácia.

Palavras-chave: Turismo, políticas públicas, eficácia.

\footnotetext{
Economista/Advogada, Doutora em Administração Pública e Governo pela Fundação Getúlio Vargas (FGV), Professora adjunta no Curso de Administração e do Mestrado Profissional em Gestão em Políticas e Organizações Públicas da Universidade Federal de São Paulo (UNIFESP). E-mail: cintiamolleraraujo@terra.com.br / Universidade Federal de São Paulo - UNIFESP: Campus Osasco - Rua Angélica. 100, Osasco - SP. CEP: 06132-380
} 
LAW 1.261/2015: obstacles to implement new public policies for tourism in São Paulo - Brazil

\begin{abstract}
Law 1.261/2015 was promulgated in April 2015 and proposes democratic and transparent parameters to evaluate touristic localities, in the state of São Paulo. Actually, it creates a new category of touristic locality, i.e. the municipalities with touristic vocation, besides the current touristic resorts, and also introduces a set of technical requirements for the selection of both categories. The intention of this paper is to identify the obstacles for the implementation of the referred law, aiming at evaluating its efficacy. So, we carried out a broad bibliographic investigation, used qualitative approach and conducted a case study, which included documentary research and some methodological procedures to collect information (e.g. participant observation, semi-structures and focused interviews). We found out that there are multiple omissions that hamper the embodiment of the rights Law 1.261/2015 announces and therefore its full implementation will take at least several years. Consequently, this scenario clearly jeopardizes its efficacy.

Key words: Tourism, public policies, efficacy.
\end{abstract}

\title{
1 INTRODUCTION
}

Law 1.261, promulgated in April 29, 2015 resulted from the approval of Bill 32/2012, which went through a long path before being approved, due to the resistance of several tourism actors in the state of São Paulo. Indeed, after four years of negotiations (i.e., from March 2012 to April 2015), Bill 32/2012 was finally voted, in April 2015, giving birth to Law 1.261/2015.

Actually, Law 1.261/2015 proposes democratic and transparent parameters to evaluate touristic localities, in the São Paulo State, introducing a set of technical requirements for the selection of the touristic resorts (hereinafter referred to as TRs) and of the municipalities with touristic vocation (hereinafter referred to as MTVs). As a matter of fact, it creates this last category, namely municipalities with touristic vocation. In this sense, it proposes to expand the financial support given by the State to a larger group of touristic localities (in order to include the MTVs), in addition to the current 70 official TRs.

Finally, Law 1.261/2015 requires that a revaluation of the status of the two categories (TRs and MTVs) has to be implemented every three years. That is to say, both categories will have to go 
periodically through an assessment process to check if they fit their category criteria. As seen, Law 1.261/2015 sets new directions for the tourism in the State of São Paulo, in opposition to the traditional logic which had long prevailed, in the past, in the tourism sector in the referred state, heavily inspired by political criteria. Therefore, it represents a victory of a trend to modernize and democratize the current touristic legislation in the state of São Paulo.

In this article we seek to identify the obstacles for the implementation of Law 1.261/2015. In other words, the intent of this research is to acknowledge the difficulties for the implementation of the mentioned law, which has already been in force for more than a year, aiming at evaluating its efficacy.

\section{LITERATURE REVIEW}

Discussions on public policies require that one reflects on the role that Governments play in the public policy process. In fact, in the context of complex societies and States, such as the ones arising in the contemporary world, the prevailing theoretical perspective advocates that the state enjoys relative autonomy, since it is subject to external influences and pressures, which contribute, to some extent, to generate conditions for the implementation of public policies. (SOUZA, 2006).

Miliband (1983, p. 58) also refutes the thesis of the "[...] neutrality of the State", insisting on the idea of its relative autonomy. He notes that according to the liberal or democratic pluralist vision, the State has lost its primacy regarding the public policy process, due to the pressures coming from a plurality of groups, interests, political parties, among others, while under the Marxist approach the reduction of the State autonomy is related to the pressures put forward by lobbies, private and public organizations that support capitalism causes. So, for Miliband (1982, p. 25, 73), there is set of powerful forces which are able to influence State decisions being worth to reiterate that there are several actors " $[\ldots]$ who hold power outside the State system and whose power affects the latter [i.e. the State] to a great extent."

Likewise, Arretche (1998) states that there is no possibility of a public policy evaluation to be exclusively technical or neutral, due to the fact that there are several ways of conceiving and implementing public policies. In this sense, she understands that public 
policies could be evaluated based on the following criteria: efficacy, effectiveness and efficiency. The evaluation of the efficacy of a public policy is based on the comparison between the established goals and the achieved ones while the effectiveness is based on the impacts/outcomes of a certain public policy or program on a determined group. Therefore, in this case, the success or failure of a certain public policy is evaluated in terms of the real change in the social conditions produced by the mentioned public policy on the referred audience. As for the evaluation of efficiency, it is based on the comparison of efforts in implementing a given policy versus the results obtained. Nevertheless the author emphasizes that it is crucial to rationalize spending in face of the shortage of public resources and stresses that efficiency is a democratic goal. She also reminds that efficiency, within the public sector, cannot be evaluated based on the same criteria used by the private sector, i.e. a simple comparison between minimum costs and the best results achieved. Consequently, with regard to inequalities, it is fair to consider the possibility of using a subsidy public policy.

Saravia (2006, p. 29) emphasizes that the public policy process "[...] does ot have a manifest rationality". Thus, for him, the public policy process is not a peaceful and quiet flow of decisions, in which each actor has a clear knowledge of his role and how to accomplish it. Subirats $(2012$, p. 3$)$ also argues that currently we live in a more interdependent global society, in which the increase in institutional fragmentation can be noted and in which the State lost its relevance. In his opinion, the State is not the unique democratic representation of a set of individuals. Indeed, the State is one agent among others in the context of power relations, limited in its capacity of action. Actually, for this author, the concept of democracy and of Rule of Law require the participation of social actors, who have their interests impacted in some way by the collective problem, which they are trying to solve.

In Theodoulou's opinion $(1995$, p. 2), the notion of public policy should not be restricted to formal actors. In fact, it is known that there are informal actors that can influence and constrain the political process, being important to add that some of them hold great relevance in the context. Besides this, he believes that public policy should not be limited to the analysis of legislation, regulations, bylaws, government reports or similar ones. In truth, it also requires the analysis of other elements, in addition to the normative ones. From 
that perspective, the production of public policies is perceived as an ongoing process, which involves a set of subsequent actions concerning its implementation and evaluation.

As for the role of Government in the field of public policies, according to Kingdon (1995), it also must be considered the possible transformations that occur in its interior and its impact on the decision-making process, such as changes in Ministries and in government departments, which generate a new wave of disputes in the political arena that may impact the governmental agenda. Furthermore, he notes the existence of several groups outside the Government circle that have a strong influence over the Governmental agenda.

Lowi (1994) argues that public policy means the interpenetration between the liberal government and society, surpassing the simple notion of laws, statutes and suchlike. He also emphasizes the rise of new values in political culture, such as the trend of publicizing several decisions and information, also stressing that this tendency is very much related to the idea of public sphere which is different from the concept of state sphere.

Barroso (2009) highlights the idea that the effectiveness of a law is related to the attempt to concretize its legal precepts. In reality, and making an analogy with the public policy field, the concept of effectiveness of a public policy can be associated to the idea of implementing its precepts, i.e. to the idea of rights that become reality.

With regard to the concept of implementing public policies Cozzolino and Irving (2015) note that the process of building governance should be committed not only to the efficiency and to the effectiveness of management (i.e. the achievement of effective results with respect to the actions agreed), but also to mechanisms of social control and accountability.

Silva (2001) mentions that within the framework of the public policy process there are conflicting interests in all phases. However, during the implementation (i.e. at the stage that actions are executed), these conflicts tend to become more evident. Indeed, at this stage, one can clearly observe if the actions are aligned and coherent with the established goals and objectives.

Wampler (2011) also draws attention to the importance of evaluating the impact of the participatory arenas on the public policy 
process, adding that the results these forums deliver vary greatly. Additionally, in Brazil, it is reasonable to infer that the traditional obstacles created to block the access of the most vulnerable social segments to the decision-making arenas may be partly responsible for the absence of a tradition of civic culture, contributing to inhibit a more effective participation of a variety of actors in the public policy process. However, according to Abers (2000) and Abers and Kech (2008), the advent of redemocratization (started in the 1980s) contributed to disseminate a growing desire for greater citizen participation in public life, therefore generating positive effects in the public policy process.

\subsection{Data and Methodology}

In order to accomplish this research, the authors of this paper decided to use a qualitative approach and conducted a case study. First, they carried out a documentary research (e.g., they gathered minutes of meetings, laws, bills, technical reports, etc). Following on this stage, and aiming at collecting more information about Law $1.261 / 2015$, its nature and obstacles to its implementation, they opted for some methodological procedures that included: participant observation, semi-structured interviews as well as focused interviews. With regard to the participant observation method, the researchers attended, during 2011-April/2016, several meetings that addressed issues that firstly were related to Bill 32/2012 (which originated Law $1.261 / 2015$ ) and later on to the referred law itself. So, they attended four meetings sponsored by the House of Representatives of São Paulo (hereinafter referred to as HRSP), twenty meetings organized by the Tourism Council of the State of São Paulo (COMTUR), one meeting coordinated by the Association of Touristic Resorts (APRECESP) and three meetings coordinated by Association of the Municipalities with Touristic Vocation (AMITur). They also undertook technical visits to 12 touristic municipalities in the State of São Paulo (TRs and MTVs), during 2013-2016, and participated in the four latest editions of the Congress of Tourism in the State of São Paulo, organized by the AMITur.

Participation in meetings and events of this nature allowed the researchers the access to information on laws, decrees, academic and journalistic articles, technical reports and studies related to the origins and evolution of Law 1.261/2015. Additionally, they had the 
opportunity to deepen their knowledge about the character of the existing power relations between some of these players as well as to get acquainted with their expectations/opinions with respect to the implementation of Law 1.261/2015. As a result, after processing the set of information and data collected, some inquiries still remained unanswered. Thus, during 2015 and beginning of 2016, 11 (eleven) semi-structured interviews were conducted, based on a road map that included open questions, which were targeted at strategic actors involved with the conception, approval and implementation of Law 1.261/2015. A second round of 3 (three) focused interviews was conducted in February and April of 2016, aiming at clarifying certain facts and at corroborating some perceptions.

In order to interpret the documents and the transcriptions of interviews, the content analysis technique was applied with the objective of identifying patterns and units of analysis. (BARDIN, 2011).

\subsection{Results}

The object of this research will fall on the MTVs, which is the new category of touristic municipalities introduced by Law $1.261 / 2015$. As a matter of fact, with regard to the other category, i.e. the already existing TRs, it seems not to be relevant to approach, in this paper, their currently situation due to the fact that there is no novelty about their present status as their reclassification will only take place in 2018.

With reference to the difficulties to implement Law $1.261 / 2015$, at first, some omissions were identified that hampered its regulation. Indeed, in order for the referred law to be implemented, it is necessary an ordinary law - which does not exist yet -, that will have the purpose of regulating it. Actually this ordinary law will detail and clarify the procedures/criteria for the classification of the MTVs and reclassification of the TRs. However, on one hand, there is not even a project of such ordinary law under consideration at the HRSP. On the other hand, it should be stressed that there is already a draft of a project of the mentioned law, which incorporated the contributions coming from the Secretary of Tourism of the State of São Paulo (hereinafter referred to as SECTOUR). This draft has already been sent to the Office of the Governor of São Paulo, where a final approval is expected, for subsequent submission to HRSP. Notwi- 
thstanding, even in face of the non-existence of an ordinary law, it is worth noting that SECTOUR tried to fill this gap, and consequently, prepared and distributed a guidebook to the municipalities which aspire to become MTVs. The mentioned guidebook is based on the principles established by Law 1261/2015 and provides suggestions on how these municipalities should proceed.

A second obstacle is related to the relationship between the municipalities that wish to become MTVs and HRSP. So, even though Law 1.261/2015 hasn't been regulated, some municipalities have already started sending their processes to HRSP (with suggested supporting documents), willing to plead the condition of a MTV. In other words, since April 2015, a group of 193 municipalities has already sent to HRSP their processes with the objective of becoming a MTV. HRSP, in turn, has forward them to its Commission of Constitution \& Justice (hereinafter referred to as CCJ) for analysis. The CCJ of HRSP is responsible for assessing these processes - i.e. analyze/check if all required documents are included or are suitable - and endorse them or not. The ones endorsed will proceed to the next level. The results, until now, are: the CCJ of HRSP examined all the above mentioned 193 processes, endorsed $11^{1}$ and didn't approve 182. In fact, the last ones (i.e. the 182 processes that were not approved) were incomplete in relation to the generic requirements of the law (e.g. absence/inadequacy of documents). So, the CCJ of HRSP returned these processes to the offices of the state deputies (i.e. the ones who are responsible for the referral of the processes), requesting corrections/adjustments. From there, the regular flow requires the state deputies to send the processes to the mentioned municipalities, requesting them to make the necessary changes/inclusion of documents. After this step, and imagining the referred municipalities concluded the corrections, the processes must return to the CCJ of HRSP, to continue their regular course. However, the second obstacle is related to the fact that it was identified that many processes not approved by the CCJ of HRSP are stuck in the deputies' offices, which should have sent them back to the municipalities so that they could make the needed corrections. With respect to the processes approved by the CCJ of HRSP, they are 11, as cited before, and were sent very recently to the SECTOUR, for further analysis.

A third, fourth and fifth obstacles are related to SECTOUR itself. In fact, if all the 193 processes before mentioned arrive to SECTOUR, they will be subject to an additional analysis (based on 
touristic criteria). Thus, SECTOUR will proceed with an evaluation - approving them or not - and next, these processes will be sent back to the CCJ of HRSP. Within SECTOUR, the third obstacle is associated to the non-existence of an internal flowchart clarifying the flow these processes should follow. Actually, according to SECTOUR's technicians interviewed in this research, it was not clear to which departments or sectors of SECTOUR these processes should be sent to be examined. Furthermore, as to the fourth obstacle, it is also known that SECTOUR is understaffed to carry out the needed technical analysis (related to touristic aspects).

The fifth difficulty is also linked to SECTOUR, and refers to a subsequent stage. In fact, this subsequent stage will take place after the processes of the municipalities aspiring to the condition of MTVs are evaluated, and, if endorsed by experts of SECTOUR, sent back for final approval by HRSP. If this happens, these municipalities become, at last, MTVs. Consequently, these MTVs will be entitled to have access to State financial resources that are guaranteed by Law 1.261/2015. However, as prerequisite, they must send drafts of the engineering/architectural projects they want to develop/built in their municipalities (e.g. the building of a Convention Center) to the SECTOUR (more specifically to the Department for the Development of the Touristic Municipalities - DDTM), in order to have them approved. Indeed, the DDTM is the technical body of SECTOUR, responsible for assessing (approving or not) these engineering/architectural projects, as well as for transferring and controlling the State funding associated to these projects. Actually, the fifth obstacle is associated to the foreseen rising demand of services that will be directed to the DDTM, which currently has already a small staff of employees (mainly engineers and architects). In fact, it is worth to highlight that nowadays the referred staff is quite reduced, even to deal with the 70 existing TRs. So, with regards to the additional demand that will probably come from the future 140 MTVs, if the DDTM's staff remains the same, this organism will certainly face great difficulties to perform its tasks.

Finally, there is yet another relevant obstacle, related to Bill of the Fund for Improvement of the Tourist Municipalities. This Bill - which establishes the rules for granting government financial resources to MTVs and RTs - is ready to be submitted to the plenary of HRSP, for the deputies to vote. Nevertheless, it is known that HRSP is in the midst of several negotiations with the Executive Power. 
Thus, depending on how these negotiations evolve they will set the conditions that will allow (or not) the mentioned Bill to be sent to the plenary for voting.

Consequently, until Bill of the Fund for Improvement of the Tourist Municipalities is not voted, and the other obstacles mentioned before remained, the regulation, effectiveness and efficacy of Law 1.261/2015 will be jeopardized and the MTVs and RTs will not be able to receive the State financial resources which they are eligible to ${ }^{2}$.

\subsection{Discussion and Conclusion}

The intent of this research was to identify the obstacles for the implementation of Law 1.261/2015, aiming at evaluating its efficacy $^{3}$. Actually, based on Theodoulou (1995), the production of public policies could be perceived as an ongoing process, which includes, besides its conception, other stages as the implementation and evaluation. Therefore, checking the status of the implementation of the legal precepts professed by any law should be viewed, likewise, as an important part of the production of public policies analysis. In doing so, with regard to Law $1.261 / 2015$, it was noticed that the referred law faces multiple difficulties to become a reality, as there are several omissions that could hamper the embodiment of the rights it announces. In fact, there are obstacles related to its regulation, to the lack of a flowchart that the processes sent by MTVs should follow inside SECTOUR, as well as to the shortage of technical personal to carry out the various tasks inside SECTOUR, not to mention the communication difficulties regarding the multiple actors involved in this network, among other noted difficulties.

Moreover, it is also noticeable, as pointed out by Miliband $(1982,1983)$, the non-neutrality of several actors (e.g. state deputies, SECTOUR employees, the Office of the Governor of the state of São Paulo, etc.) that participate in this process and openly try to influence its timing and the final decisions. With respect to the clash of interests observed in the referred process, it reminds Silva's work (2001) which emphasizes that along the public policy process there are several conflicting interests However, she stresses that they become more evident during the implementation stage.

In the end, in face of the facts reported here, it seems reasonable to accept Saravia's statement $(2006$, p. 29) that "[...] the 
public policy process does not have a manifest rationality." So, the aforementioned findings lead to the conclusion that the full implementation of Law 1.261/2015 will take at least several years and this scenario clearly compromises not only its efficacy but also its effectiveness.

\section{REFERENCES}

ABERS, R. Inventing local democracy: grassroots politics in Brazil. London: Lynne Rienner Publishers, 2000.

ABERS, R.; KECH, M. Representando a diversidade: Estado, sociedade e "relações fecundas" nos conselhos gestores. Caderno CRH, Salvador, v. 21, n. 52, p. 99-112, 2008.

ARRETCHE, M. Tendências no Estudo de Avaliação. In: RICO, E. (Org). Avaliação de políticas sociais: uma questão em debate. São Paulo: Cortez, 1998. p. 29-39.

BARDIN, L. Análise de conteúdo. São Paulo: Edições 70, 2011.

BARROSO, L. O direito constitucional e a efetividade de suas normas. $9^{\mathrm{a}}$ ed. Rio de Janeiro: Renovar, 2009.

COZZOLINO, L.; IRVING, M. Por uma concepção democrática de governança para a esfera pública. Revista de Políticas Públicas, São Luís, v. 19, n. 2, p 497-508, jul./dez. 2015.

KINGDON, J. Agendas, alternatives, and public policies. 2. ed. New York: HarperCollins, 1995. Cap. 7 -The Political Stream.

LOWI, T. O Estado e a ciência política ou como nos convertemos naquilo que estudamos. Revista Brasileira de Informação Bibliográfica em Ciências Sociais - BIB, Rio de Janeiro, n. 38, p. 3-14, jul./dez. 1994.

MILIBAND, R. O Estado na sociedade capitalista. 2. ed. Rio de.Janeiro: Zahar Editores, 1982.

State power \& class interests. New Left Review, 138, p. 5768, mar./apr. 1983.

SARAVIA, E. Introdução à teoria política pública. In: SARAVIA, E.; FERNANDES, E. (Orgs.). Políticas Públicas. Brasília, DF: ENAP, 2006. v. I, p. 21-42.

SILVA, M. O. S. Avaliação de políticas e programas socias: teoria e prática. São Paulo. Veras Editora, 2001. 
SOUZA, C. Políticas Públicas: uma revisão da literatura. Sociologias, Porto Alegre, ano 8, n. 16, p. 20-45, jul./dez. 2006.

SUBIRATS, J. Nuevos tempos? Nuevas políticas públicas? Explorando caminhos de respostas. Revista Del CLAD Reforma y Democracia, Caracas, n. 54, oct. 2012.

THEODOULOU, S. The nature of public policy. In: ; CAHN, M. Public policy: the essential readings. New Jersey: Prentice Hall, Upper Saddle River, 1995.

WAMPLER, B. Que tipos de resultados devemos esperar das instituições participativas? In: PIRES, R. R. C. (Org.). Efetividade das instituições participativas no Brasil: estratégias de avaliação. Brasília, DF: IPEA, 2011. p. 43-51.

\section{NOTES}

1 The eleven municipalities endorsed by the CCJ of HRSP are: Buritama, Brodowski, Rifaina, Espírito Santo do Pinhal, Santa Branca, Tatuí, Rubinéia, Itariri, Itapiraí, Iacanga, Ourinhos.

2 The notions of efficacy and effectiveness used in this article are based on Arretche's concept, presented in her work Tendências no Estudo de Avaliação, mentioned along this paper and also in the References.

3 For more information, it is recommended to check Arretche's concept regarding efficacy, mentioned in this article. 